\title{
METHODS FOR DNA QUANTIFICATION YIELD SIMILAR RELATIVE BUT DIFFERENT ABSOLUTE VALUES
}

Balanovsky OP ${ }^{1,2,3 凶}$, Kagazezheva ZhA ${ }^{1,2}$, Olkova MV²

${ }^{1}$ Vavilov Institute of General Genetics, Moscow, Russia

${ }^{2}$ Research Center for Medical Genetics, Moscow, Russia

${ }^{3}$ Biobank of North Eurasia, Moscow, Russia

\begin{abstract}
DNA quantification is a routine yet important procedure that determines the efficacy of long-term sample storage and further manipulations with the sample. There are a few well-established methods for measuring DNA concentrations. However, it still not fully clear how concordant their results are. The aim of this work was to measure DNA concentrations in a set of samples using different quantification methods and to compare the obtained values. In 2 independent experiments, a total of 100 genomic DNA samples were analyzed using 3 different DNA quantification methods, including spectrophotometry (NanoDrop), fluorometry (Qubit) and real-time PCR (Quantifiler). The obtained relative concentrations demonstrated an excellent correlation (the correlation coefficients were as high as 0.98 to 0.99 ). However, the absolute concentrations showed a considerable variation and even a twofold difference. Spectrophotometry yielded the highest concentrations, whereas fluorometry yielded the lowest. The real-time PCR results were intermediate. The differences were more pronounced for the samples with low DNA concentrations. We recommend that such differences should be accounted for when estimating DNA concentrations using an arsenal of different quantification methods
\end{abstract}

Keywords: DNA concentration, measurement method, real-time PCR, spectrophotometry, fluorometry

Funding: this study was part of the Government contract with the Research Center for Medical Genetics (Experiment 1). Experiment 2 was supported in part by Grant 17-14-01345 of the Russian Science Foundation.

Author contribution: Balanovsky OP conceived the study, analyzed the obtained data and wrote this manuscript; Kagazezheva ZhA conducted one of the experiments; Olkova MV conducted one of the experiments and analyzed the literature.

Compliance with ethical standards: the study was approved by the Ethics Committee of the Research Center for Medical Genetics (Protocol № 3/1 dated september 5, 2018). The analyzed samples were obtained during population genetic studies. All study participants gave informed consent to participate.

$\triangle$ Correspondence should be addressed: Oleg P. Balanovsky

Gubkina 3, Moscow, 119991; balanovsky@inbox.ru

Received: 21.06.2019 Accepted: 27.06.2019 Published online: 30.06.2019

DOI: 10.24075/brsmu.2019.043

\section{МЕТОДЫ ИЗМЕРЕНИЯ КОНЦЕНТРАЦИИ ДНК: СОВПАДЕНИЕ ОТНОСИТЕЛЬНЫХ ВЕЛИЧИН И РАЗЛИЧИЯ АБСОЛЮТНЫХ}

О. П. Балановский ${ }^{1,2,3}$, Ж. А. Кагазежева ${ }^{1,2}$, М. В. Олькова ${ }^{2}$

${ }^{1}$ Институт общей генетики имени Н. И. Вавилова, Москва, Россия

${ }^{2}$ Медико-генетический научный центр, Москва, Россия

${ }^{3}$ Биобанк Северной Евразии, Москва, Россия

\begin{abstract}
Измерение концентрации ДНК является базовым методом, от надежности которого зависит эффективность дальнейшего хранения и использования образцов. Существует несколько широко распространенных и хорошо зарекомендовавших себя способов измерения концентрации ДНК, однако степень их согласованности друг с другом изучена недостаточно. Целью работы было измерить концентрации одних и тех же образцов разными методами и провести сравнительный анализ полученных результатов. В двух независимых экспериментах, суммарно включивших 100 образцов геномной ДНК, сравнивали три метода определения концентрации ДНК: спектрофотометрический (Nanodrop), флуориметрический (Qubit) и ПЦР в реальном времени (Quantifiler). Выявлено, что значения концентрации ДНК, полученные разными методами, хорошо коррелируют друг с другом (коэффициенты корреляции составляют 0,98-0,99). Однако при такой отличной корреляции относительных величин концентрации абсолютные величины, полученные разными методами, варьируют значительно, вплоть до двукратных различий. Спектрофотометрический метод дает наиболее высокие концентрации, ПЦР в реальном времени - промежуточные, а флуориметрический — наиболее низкие. Различия в результатах более выражены для образцов с низкой концентрацией. Мы рекомендуем учитывать наличие этих систематических различий между результатами измерения концентрации ДНК, полученными разными методами.
\end{abstract}

Ключевые слова: концентрация ДНК, методы измерения, ПЦР в реальном времени, спектросотометрический метод, флуориметрический метод

Финансирование: исследование выполнено в рамках Государственного задания для Медико-генетического научного центра (эксперимент 1) и при поддержке гранта РНФ 17-14-01345 (эксперимент 2).

Информация о вкладе авторов: О. П. Балановский - дизайн исследования, анализ данных, написание текста статьи; Ж. А. Кагазежева - проведение экспериментальных работ; М. В. Олькова - проведение экспериментальных работ, подбор литературы.

Соблюдение этических стандартов: исследование выполнено на образцах, полученных в ходе популяционно-генетических обследований генофонда и одобрено Этическим комитетом Медико-генетического научного центра (протокол № 3/1 от 5 сентября 2018 г.). Все участники исследования подписали добровольное информированное согласие на участие в исследовании и публикацию данных.

$\bigotimes$ Для корреспонденции: Олег Павлович Балановский

ул. Губкина, д. 3, г. Москва, 119991; balanovsky@inbox.ru

Статья получена: 21.06.2019 Статья принята к печати: 27.06.2019 Опубликована онлайн: 30.06.2019

DOI: $10.24075 /$ vrgmu.2019.043

DNA quantification is a routine procedure performed by many laboratories. It is an important part of sample preparation for long-term storage, biobanking or NGS. There are a few wellestablished methods for measuring DNA concentrations that have been conveniently translated into commercially available reagent kits and instrumentation. Still, it is not uncommon that different methods yield different estimates. The available literature [1-6] warns against the limitations and specific characteristics of DNA quantification methods that the end user may not be fully aware of. Genomic DNA and DNA 
library concentrations are measured prior to whole-genome sequencing, as part of a sample reception procedure or while monitoring the quality of stored DNA samples. In our lab, we work with extensive sample collections from the Biobank of North Eurasia [7], among other projects; therefore, it is critical for us to find an optimal method for DNA quantification, understand the nuances of its application and compare it to other existing measurement methods. It is highly likely that other laboratories may face a similar task. The aim of this work was to measure DNA concentrations in a series of samples using different quantification methods and compare the obtained values by assessing the repeatability of each method, determining the concordance of the results and identifying the trends of differences between the obtained values.

\section{METHODS}

In 2017-2018 we conducted a series of experiments in which we measured DNA concentrations in a set of samples using different quantification methods. The following DNA quantification methods were compared: a) NanoDrop spectrophotometry, which can determine both DNA concentration and DNA quality from the absorbance of a sample at a certain wavelength; b) fluorescence-based measurements using fluorescent dyes (Qubit); c) real-time PCR (Human DNA Quantifiler).

All the experiments gave the same picture, so in this article we will talk about the most elaborately planned experiments (1 and 2) in which the number of controlled variables was the highest. In both experiments, we used DNA samples from the Biobank of North Eurasia obtained through phenol-chloroform extraction.

In experiment \#1, 49 DNA samples were analyzed. Prior to the experiment, DNA concentrations were estimated using a Qubit fluorometer and Qubit reagent kits. Highly concentrated samples were diluted down to $<50 \mathrm{ng} / \mu \mathrm{l}$ because the Human Quantifiler kit guarantees accurate measurements only at concentrations below $55 \mathrm{ng} / \mu \mathrm{l}$, given that standard dilution series are prepared in strict accordance with the manufacturer's guidelines. In those 49 samples, DNA concentrations were measured in 3 ways: spectrophotometrically in 3 replicates per sample using a NanoDrop spectrophotometer; fluorescently in 3 replicates per sample using Qubit instrumentation and reagent kits; using real-time PCR and a Human DNA Quantifiler kit. Due to high costs of the reagents, real-time PCR was conducted in 2 replicates for half of the samples. Because the correlation between the replicates was 0.99 , DNA concentrations in the rest of the samples were measured only once per sample.

For spectrophotometry, we used NanoDrop 2000 (Thermo Fisher Scientific; USA) in strict compliance with the manufacturer's protocol. DNA samples were aspirated into an automatic Research Plus pipette (Eppendorf; Germany) that allows adjusting the dispensed volume between 1 and $10 \mu \mathrm{l}$. DNA concentrations were measured in $2 \mu \mathrm{l}$ samples at $20^{\circ} \mathrm{C}$.

Fluorescence measurements were done using a Qubit 4 fluorometer (Thermo Fisher Scientific; USA), compatible $0.5 \mathrm{ml}$ thin-walled assay tubes by the same manufacturer and Qubit ${ }^{\mathrm{TM}}$ dsDNA BR Assay Kits (Thermo Fisher Scientific; USA) in strict accordance with the manufacturer's protocol [7]. Samples were aspirated into an 0.1-2.5 $\mu$ automatic Research Plus pipette (Eppendorf; Germany). DNA concentrations were measured in $2 \mu \mathrm{l}$ samples at $20^{\circ} \mathrm{C}$.

Real-time PCR was performed using a 7500 Real-Time PCR System for Human Identification (Applied Biosystems; USA) and a Quantifiler ${ }^{\mathrm{TM}}$ Human DNA Quantification Kit (Thermo Fisher Scientific; USA) in strict compliance with the manufacturer's protocol. Samples were aspirated into an automated 0.1-2.5 $\mu \mathrm{l}$ Research Plus pipette (Eppendorf; Germany). Two $\mu$ of each sample were amplified.

In experiment \#2, 51 DNA samples were analyzed. Methods, reagent kits and instrumentation applied to measure DNA concentrations were the same as in experiment 1. Fluorescence measurements were done in 2 replicates. Other measurements were performed in one replicate per sample. Prior to the experiment, DNA concentrations were estimated using a Qubit fluorometer and Qubit reagent kits. The range of DNA concentrations measured in experiment 2 was shifted upward to $20-90 \mathrm{ng} / \mathrm{\mu l}$.

Experiments 1 and 2 were conducted by different researchers at different time points. Initial data processing and graph construction were done in MS Excel; correlation coefficients were computed in Statistica 7.

\section{RESULTS}

Results of experiments 1 and 2 are shown in Tables 1 and 2, respectively. Because the experiments were of the same type, their results are presented together in the Figure and Tables 3 and 4. First, a more detailed experiment 1 is described and then its results are compared to the results of experiment 2.

We started analyzing the data collected in experiment 1 by calculating the repeatability of the results obtained with one and the same DNA quantification method in a few replicates per sample. The repeatability turned out to be extremely high: the correlation coefficient varied between 0.99 and 1.00, which at the very least suggests the absence of a pipetting error. Therefore, for each sample, mean concentrations of all replicates were used for further analysis.

Since real-time PCR-based DNA quantification (below referred to as Quantifiler) is considered to be the most accurate, we used it as a reference method. Values obtained with other methods were compared to those yielded by Quantifiler. We would like to emphasize that a different choice of a reference method would have led us to the same conclusions. In Figure 1A, DNA concentrations obtained with real-time PCR are plotted on the X-axis. DNA concentrations obtained using all three analyzed methods are plotted on the Y-axis. The Quantifiler curve can only take a form of a 45 degree line (the black line in the picture). It serves as a baseline. The 2 other curves look more interesting.

The NanoDrop curve (Fig. 1A; the orange one) was constructed from the values that on the whole were concordant with Quantifiler estimates. Still, they were a bit higher, with stochastic fluctuations ("beats"). The NanoDrop spectrophotometer returned higher DNA concentrations than the Quantifiler kit for the samples containing $20 \mathrm{ng} / \mu \mathrm{l}$ DNA. For lower DNA concentrations, both methods generated very similar results.

In the Figure, the orange NanoDrop curve lies above the black Quantifiler line, and the blue Qubit curve is below the latter. For all our samples, Qubit generated lower concentration values, as compared to Quantifiler. Unlike the NanoDrop curve, the Qubit curve looks smoother, suggesting better stability of measurements. The first impression of the Qubit curve is that the distance between its every point and every corresponding point of the Quantifiler line is fixed. However, the blue dotted trendline demonstrates that the Qubit curve is not only characterized by lower DNA concentrations but also has a different slope.

The next step was quantitative analysis. Table 3 (specifically, the values above the diagonal) shows correlations between the results obtained with 3 tested DNA quantification methods. The correlation coefficients were very high (at least 0.98), 
Table 1. Results of DNA quantification in individual samples (Experiment 1)

\begin{tabular}{|c|c|c|c|c|c|c|c|c|}
\hline SampleID & Quantifiler1 & Quantifiler2 & Qubit1 & Qubit2 & Qubit3 & Nanodrop1 & Nanodrop2 & Nanodrop3 \\
\hline 21 & 10.7 & 10.3 & 6.1 & 5.9 & 5.6 & 11.6 & 13.1 & 12.0 \\
\hline 22 & 18.3 & 17.6 & 12.2 & 11.2 & 11.4 & 23.7 & 25.0 & 24.1 \\
\hline 23 & 36.6 & 33.2 & 24.4 & 24.1 & 24.0 & 51.6 & 51.2 & 49.8 \\
\hline 24 & 44.2 & 47.8 & 34.0 & 36.2 & 31.9 & 73.7 & 75.2 & 73.2 \\
\hline 25 & 64.3 & 58.4 & 47.2 & 45.0 & 49.6 & 101.1 & 104.4 & 102.8 \\
\hline 31 & 10.2 & 9.8 & 5.5 & 5.4 & 5.6 & 8.6 & 7.9 & 8.0 \\
\hline 32 & 18.1 & 18.3 & 11.2 & 11.0 & 10.9 & 15.7 & 16.4 & 17.1 \\
\hline 33 & 37.0 & 35.7 & 23.6 & 24.5 & 23.4 & 38.6 & 37.6 & 39.5 \\
\hline 34 & 44.7 & 47.4 & 32.9 & 30.1 & 31.4 & 51.5 & 54.4 & 51.7 \\
\hline 35 & 59.2 & 54.4 & 42.1 & 43.3 & 42.6 & 67.8 & 70.7 & 69.4 \\
\hline 41 & 10.3 & 9.7 & 5.6 & 6.1 & 5.2 & 8.2 & 7.7 & 7.5 \\
\hline 42 & 14.8 & 15.5 & 11.6 & 11.0 & 10.9 & 16.3 & 16.9 & 16.2 \\
\hline 43 & 28.7 & 27.3 & 22.3 & 23.0 & 22.7 & 35.8 & 35.8 & 36.8 \\
\hline 44 & 40.1 & 39.8 & 32.8 & 32.3 & 33.5 & 53.2 & 51.5 & 53.4 \\
\hline 45 & 59.0 & 55.3 & 45.3 & 45.7 & 46.0 & 70.7 & 71.9 & 71.7 \\
\hline 51 & 10.1 & 10.5 & 5.9 & 5.7 & 5.5 & 10.0 & 9.3 & 9.3 \\
\hline 52 & 20.1 & 20.2 & 11.8 & 11.6 & 11.5 & 19.9 & 19.2 & 19.5 \\
\hline 53 & 34.2 & 35.8 & 23.2 & 22.0 & 23.4 & 38.4 & 39.4 & 36.3 \\
\hline 54 & 47.7 & 44.6 & 31.9 & 33.7 & 34.0 & 59.5 & 57.8 & 58.1 \\
\hline 71 & 9.0 & 8.8 & 5.3 & 5.4 & 5.1 & 8.1 & 8.1 & 8.4 \\
\hline 72 & 15.5 & 15.4 & 9.7 & 10.3 & 10.3 & 17.2 & 17.5 & 17.7 \\
\hline 73 & 28.2 & 30.6 & 18.5 & 19.5 & 19.1 & 36.3 & 36.1 & 36.3 \\
\hline 74 & 42.3 & 44.6 & 34.2 & 27.7 & 30.3 & 54.3 & 52.7 & 54.1 \\
\hline 75 & 53.0 & 58.1 & 40.6 & 46.3 & 41.9 & 75.2 & 72.1 & 72.6 \\
\hline 81 & 10.8 & & 5.8 & 5.7 & 5.8 & 9.1 & 9.0 & 9.0 \\
\hline 82 & 23.1 & & 11.8 & 11.6 & 11.8 & 20.4 & 19.3 & 19.5 \\
\hline 83 & 32.7 & 32.4 & 21.9 & 21.7 & 21.2 & 36.5 & 37.5 & 36.8 \\
\hline 84 & 48.3 & & 32.0 & 33.6 & 33.9 & 59.7 & 58.0 & 58.3 \\
\hline 85 & 63.6 & & 45.6 & 46.9 & 47.0 & 77.1 & 80.5 & 80.5 \\
\hline 91 & 10.9 & & 5.7 & 5.8 & 5.8 & 10.2 & 9.8 & 9.8 \\
\hline 92 & 19.4 & & 11.7 & 11.9 & 10.9 & 22.4 & 23.3 & 23.5 \\
\hline 93 & 33.9 & & 22.2 & 22.9 & 23.0 & 46.2 & 47.0 & 46.0 \\
\hline 94 & 51.5 & & 36.0 & 35.5 & 36.0 & 70.3 & 70.9 & 69.6 \\
\hline 95 & 62.2 & & 40.3 & 45.3 & 46.6 & 92.3 & 90.2 & 91.5 \\
\hline 101 & 10.1 & & 5.6 & 5.9 & 5.7 & 10.7 & 10.5 & 11.6 \\
\hline 102 & 22.4 & & 12.5 & 12.3 & 12.2 & 23.8 & 24.6 & 21.9 \\
\hline 103 & 39.0 & & 22.0 & 23.3 & 22.8 & 50.3 & 50.7 & 50.0 \\
\hline 104 & 51.9 & & 32.2 & 34.0 & 34.1 & 70.4 & 70.6 & 68.0 \\
\hline 105 & 63.0 & & 44.7 & 46.4 & 46.4 & 95.0 & 92.0 & 95.5 \\
\hline 111 & 8.3 & & 4.5 & 4.7 & 4.7 & 7.0 & 7.5 & 7.7 \\
\hline 112 & 17.4 & & 10.1 & 10.3 & 10.0 & 14.9 & 14.9 & 16.3 \\
\hline 113 & 30.2 & & 18.0 & 19.6 & 20.2 & 31.5 & 33.0 & 29.8 \\
\hline 114 & 43.6 & & 28.8 & 28.3 & 30.0 & 45.6 & 44.6 & 46.2 \\
\hline 115 & 56.9 & & 39.3 & 41.8 & 40.5 & 62.8 & 63.3 & 61.4 \\
\hline 121 & 9.8 & & 5.3 & 5.1 & 4.8 & 10.3 & 9.9 & 10.4 \\
\hline 122 & 20.5 & & 10.4 & 10.9 & 11.2 & 21.0 & 21.8 & 21.9 \\
\hline 123 & 36.2 & & 22.3 & 22.6 & 23.5 & 43.9 & 43.7 & 42.4 \\
\hline 124 & 49.4 & & 32.6 & 32.3 & 32.0 & 63.0 & 64.2 & 63.9 \\
\hline 125 & 56.4 & & 41.9 & 41.5 & 42.8 & 84.0 & 82.8 & 81.9 \\
\hline
\end{tabular}


Table 2. Results of DNA quantification in individual samples (Experiment 2)

\begin{tabular}{|c|c|c|c|c|}
\hline SampleID & Nanodrop & Qubit1 & Qubit2 & Quantifiler \\
\hline 1 & 67.5 & 45.4 & 50.2 & 56.0 \\
\hline 2 & 71.9 & 51.2 & 52 & 56.2 \\
\hline 3 & 99.1 & 78 & 65.1 & 78.5 \\
\hline 4 & 59.2 & 47.5 & 49 & 48.4 \\
\hline 8 & 97.1 & 69.7 & 76.2 & 83.7 \\
\hline 10 & 76.4 & 67.2 & 65.9 & 68.1 \\
\hline 11 & 58 & 46.7 & 43.3 & 46.6 \\
\hline 12 & 88.7 & 66.8 & 63.7 & 73.1 \\
\hline 13 & 59.8 & 42.2 & 40.8 & 48.9 \\
\hline 14 & 92.4 & 62.1 & 66.1 & 79.8 \\
\hline 15 & 78.6 & 50.4 & 51.8 & 62.7 \\
\hline 16 & 74.3 & 50.7 & 51.4 & 60.5 \\
\hline 17 & 72.5 & 29.6 & 48.4 & 43.6 \\
\hline 18 & 47.5 & 34.6 & 35.5 & 39.0 \\
\hline 19 & 84.5 & 59.1 & 59.8 & 63.7 \\
\hline 20 & 98.5 & 71.2 & 77 & 83.5 \\
\hline 21 & 69.9 & 56.4 & 61.3 & 68.5 \\
\hline 26 & 66.2 & 45.2 & 33.8 & 62.3 \\
\hline 27 & 100.1 & 54.9 & 77.9 & 81.3 \\
\hline 28 & 97 & 74.1 & 75 & 79.5 \\
\hline 29 & 95.6 & 62.8 & 68.1 & 72.4 \\
\hline 32 & 58.5 & 39.2 & 40.6 & 41.5 \\
\hline 33 & 71.3 & 47.4 & 44.3 & 61.1 \\
\hline 34 & 82.6 & 43 & 64.1 & 75.3 \\
\hline 35 & 101.7 & 69.2 & 74.1 & 86.5 \\
\hline 37 & 101.6 & 73.3 & 74 & 84.5 \\
\hline 44 & 101.7 & 49.8 & 48.3 & 70.2 \\
\hline 46 & 99.2 & 86 & 63.6 & 93.9 \\
\hline 48 & 101.7 & 70.7 & 78.5 & 80.1 \\
\hline 49 & 50.9 & 36.5 & 37.5 & 41.2 \\
\hline 51 & 50.8 & 27.4 & 29.8 & 34.8 \\
\hline 52 & 48.1 & 38.7 & 42.2 & 50.3 \\
\hline 53 & 52.6 & 31.9 & 46.1 & 54.4 \\
\hline 54 & 27.2 & 18.3 & 15.9 & 23.1 \\
\hline 55 & 52.5 & 34.6 & 36.8 & 36.7 \\
\hline 56 & 55.8 & 32.7 & 34.7 & 72.3 \\
\hline 57 & 50.2 & 31.2 & 35.8 & 50.1 \\
\hline 58 & 62.7 & 58.2 & 50.9 & 28.5 \\
\hline 59 & 36.3 & 23.2 & 26.7 & 25.7 \\
\hline 60 & 18.5 & 11.4 & 11.9 & 31.9 \\
\hline 61 & 34.8 & 22.2 & 25.9 & 27.1 \\
\hline 62 & 73.3 & 28.2 & 55.9 & 66.6 \\
\hline 63 & 112.5 & 50 & 90.2 & 92.2 \\
\hline 65 & 54.1 & 21.7 & 36 & 42.3 \\
\hline 72 & 63.3 & 42.9 & 50.6 & 53.4 \\
\hline 73 & 66.9 & 40.1 & 36.5 & 50.0 \\
\hline 74 & 68.9 & 40.2 & 47.4 & 50.4 \\
\hline 75 & 41.1 & 25.4 & 24.7 & 29.1 \\
\hline 76 & 75 & 43.3 & 51.4 & 63.8 \\
\hline 77 & 71.7 & 51.1 & 50.4 & 61.2 \\
\hline 79 & 99.7 & 64.8 & 64.9 & 74.9 \\
\hline
\end{tabular}


A

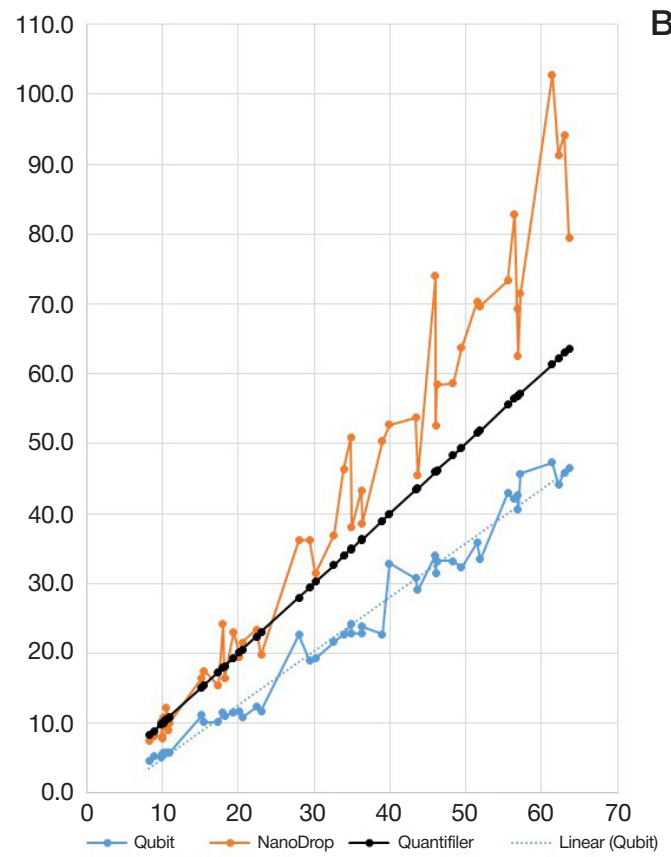

B

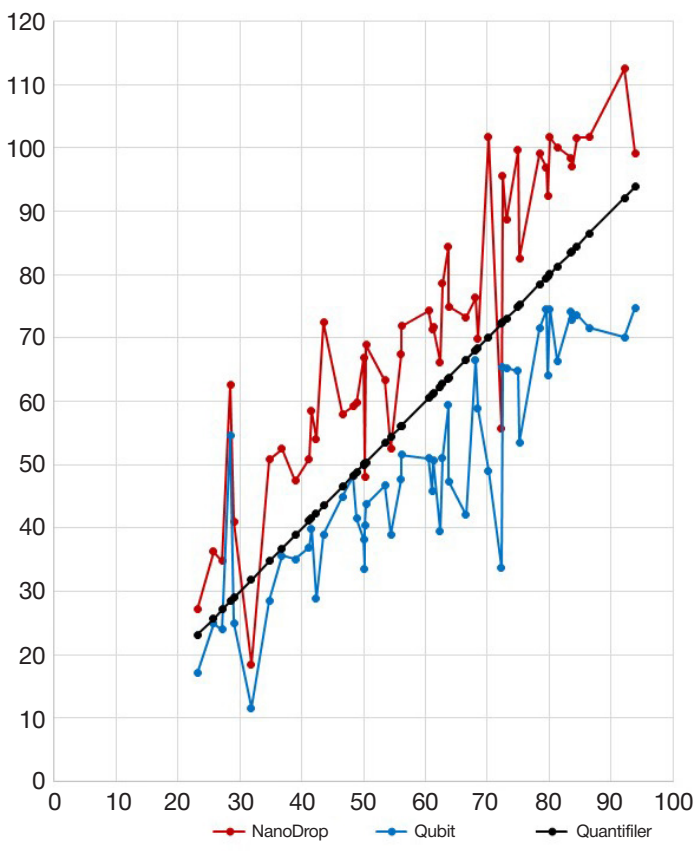

Fig. 1. DNA concentrations in individual samples measured using different methods. A: Experiment 1. B Experiment 2. The X-axis: concentrations yielded by Quantifiler. The Y-axis: concentrations yielded by Quantifiler (the black line), Qubit (the blue line) and NanoDrop (the red line).

demonstrating excellent correlation between the values produced by different measurement methods. However, this was not the case with the mean values (Table 4). Most importantly, mean Qubit values were significantly (1.5 times) lower than mean Quantifiler values, whereas mean DNA concentrations measured with NanoDrop were by 25\% higher than those measured with Quantifiler. Moreover, the variability of the obtained values depended on a DNA concentration in the studied sample. When the total sample was split into two subsets of equal sample size and different concentrations, the ratio of mean Qubit/Quantifiler values reached 61\% for the samples with lower DNA concentrations and $71 \%$ for the samples with higher concentrations (Table 4; differences were considered significant at $p=0.01$; the Mann-Whitney $U$ test was applied). So, in order to study the relationship between DNA concentrations and differences in the values obtained using different quantification methods, we arranged the total sample into 5 subsets in the ascending order of concentrations and calculated the ratio of Qubit to Quantifiler concentrations (Table 4). Although the size of the subgroups was small (10 samples per subset), we managed to identify a distinct trend: the ratio of Qubit to Quantifiler concentrations increased monotonously from 55\% (twofold differences at low concentrations) to 75\% (a 25\% difference at high concentrations).

The results described above pertain to experiment 1 . In experiment 2, the graph (Fig. 1B) demonstrates the same trend for individual samples: in comparison with real-time PCR-derived concentrations (Quantifiler), NanoDrop values (the red curve) are higher and Qubit values (the blue curve) are lower. Statistical noise (the chaotic character of the curves) was more pronounced in experiment 2, which we attributed to the operator effect. Similar to experiment 1, the results yielded by the studied DNA quantification methods were wellcorrelated. However, they were affected by the operator effect: although the correlation coefficients were high (0.88-0.93) in experiment 2 (Table 3; the values under the diagonal), they

Table 3. Correlation coefficients for DNA concentrations yielded by different quantification methods. Above diagonal: experiment 1. Below diagonal: experiment 2

\begin{tabular}{|c|c|c|c|}
\hline & Quantifiler & Qubit & Nanodrop \\
\hline Quantifiler & 1 & 0.99 & 0.98 \\
\hline Qubit & 0.93 & 1 & 0.98 \\
\hline Nanodrop & 0.91 & 0.88 & 1 \\
\hline
\end{tabular}

Table 4. Mean DNA concentrations yielded by different quantification methods

\begin{tabular}{|c|c|c|c|c|c|c|}
\hline & & Quantifiler & Qubit & Nanodrop & Qubit/Quantifiler & Nanodrop/Quantifiler \\
\hline \multirow{8}{*}{ Experiment 1} & All samples & 33.1 & 22.7 & 41.3 & 0.68 & 1.25 \\
\hline & lower conc $(n=24)$ & 17.0 & 10.4 & 18.0 & 0.61 & 1.05 \\
\hline & higher conc $(n=25)$ & 48.6 & 34.5 & 63.8 & 0.71 & 1.31 \\
\hline & conc_range1 $(n=10)$ & 9.9 & 5.5 & 9.3 & 0.55 & 0.94 \\
\hline & conc_range2 $(n=10)$ & 19.0 & 11.2 & 19.7 & 0.59 & 1.04 \\
\hline & conc_range3 $(n=10)$ & 33.6 & 22.2 & 40.8 & 0.66 & 1.22 \\
\hline & conc_range4 $(n=10)$ & 46.6 & 32.6 & 59.9 & 0.70 & 1.29 \\
\hline & conc_range5 $(n=10)$ & 59.2 & 44.2 & 80.8 & 0.75 & 1.36 \\
\hline Experiment 2 & All samples & 59.0 & 49.2 & 71.4 & 0.83 & 1.21 \\
\hline
\end{tabular}


were still lower than in experiment 1. Just like in experiment 1, the analysis of mean values revealed that Qubit estimates were by $20 \%$ lower than those measured with Quantifiler, whereas NanoDrop estimates were by $20 \%$ higher than those generated by Quantifiler. In experiment 2, we could not identify the relationship between the ratio of DNA concentrations measured with different quantification methods and the DNA concentration in the studied sample. We attributed this to a higher rate of experimental error in experiment 2: due to the operator effect, this relationship could not be observed in a studied sample size.

\section{DISCUSSION}

The sets of samples analyzed in our experiments were different. The experiments were conducted at different time points by differently experienced researchers. But the observed trends were similar: relative concentration values yielded by different quantification methods were well-correlated whereas absolute DNA concentrations differed significantly. Besides, the lower was the concentration, the more pronounced was the difference. This means that each of the tested quantification methods reliably measures relative concentrations, which can be further used as a reference for other samples measured using the same method. However, a problem arises when we measure DNA concentrations with different quantification methods within one study. Conversion would be a solution here (figures from two rightmost columns in Table 4 could be used as conversion coefficients), but such calculations are complicated because the conversion coefficient depends on concentrations.

Research works cited above report that different DNA quantification methods can produce concordant [1] or different $[3,4]$ results. We used a large sample set (a total of 100 samples in both experiments), whereas the majority of similar studies are carried out using only 3 to 6 samples. This allowed us to run a statistical analysis on the obtained concentration values and identify the relationship between the measured concentration and the variability of the results depending on the method applied.

Given that each of the tested methods has its own nuances, it was hard to predict the results of the experiments. On the one hand, estimates based on real-time PCR (Quantifiler) can be lower than those yielded by the Qubit fluorometer because real-time PCR measures the effective DNA concentration (i.e., long intact DNA fragments that can be amplified), whereas Qubit analyzes all the fragments. On the other hand, PCRderived values can be higher than those measured with Qubit instrumentation and dyes because real-time PCR amplifies both double- and single-stranded DNA from each analyzed sample, whereas Qubit assays are selective for double-stranded DNA only. Concentrations returned by the spectrophotometer were higher than those calculated from real-time PCR. This can be explained by the presence of phenol or protein admixtures in the sample. Phenol makes a more significant contribution because its absorbance peak occurs at $270 \mathrm{~nm}$ and overlaps with the absorbance peak of DNA at $260 \mathrm{~nm}$ wavelength.
Reference standards used (known DNA concentrations included in the reagent kit) may have contributed to the differences in the resulting concentration values. According to the information provided by the manufacturer of the Quantifiler kit, the concentration of the reference standard should be 200 $\mathrm{ng} / \mathrm{\mu l}$. However, when measured with Qubit kits and equipment, this concentration turned out to be by $5-10 \%$ lower. Of note, both Qubit and Quantifiler kits are produced by Thermo Fisher Scientific [8]. A similar problem with Quantifiler reference standards was reported in one of early works. But even if a different standard had been used, it would not have solved the problem, because the variability of the results between the methods is unstable and depends on the concentration of DNA in the sample.

Measurement discrepancies between the tested quantification methods might be to some extent determined by a few other factors pertaining to the conditions of the experiment. We worked with low-fragmented DNA obtained through phenol-chloroform extraction that was taken in a range of concentrations between 5 and $100 \mathrm{ng} / \mathrm{\mu l}$. We think that the trends we discovered will be observed for other DNA samples with a different shelf-life and different extraction methods. However, in this case DNA quantification may be affected by other factors that were not present in our experiment.

Surprisingly, NanoDrop spectrophotometry, which does not have a reputation of a reliable DNA quantification method, performed well in our experiment. Although the rate of error was a bit higher than that of Qubit (see the Figure), correlation coefficients for NanoDrop and Qubit, as well as for NanoDrop and Quantfiler, were quite high (Table 3).

We also noted the so-called operator effect: one and the same method demonstrates different repeatability when applied by different members of staff who use the same equipment and follow the same protocols. This fact is consistent with our previous observations [6].

Although no systemic errors were observed in the work of the researchers who conducted the experiments and the latter were elaborately planned, the error of measurement was different depending on who performed the procedure. We assume that the difference in measurement accuracy will be even more pronounced for routine laboratory tasks

\section{CONCLUSIONS}

We found that DNA concentrations measured in a large sample set using different quantification methods were well-correlated but the obtained values differed between the methods applied: NanoDrop spectrophotometry yielded higher concentrations, real-time PCR (Quantifiler), intermediate values, and fluorometry (Qubit), lower values. The differences were more pronounced for the samples with low DNA concentrations. We recommend that such regular differences should be accounted for when estimating DNA concentrations using an arsenal of different quantification methods. It would also be wise to explicitly specify what method and what reagent kit are used to measure DNA concentrations in your experiment even if this method is well-established and reliable.

\section{References}

1. Bhat S, Curach N, Mostyn T, Bains GS, Griffiths KR, et al. Comparison of methods for accurate quantification of DNA mass concentration with traceability to the international system of units. Anal Chem. 2010 Sep 1; 82 (17): 7185-92. DOI: 10.1021/ ac100845m.

2. Li X, Wu Y, Zhang L, Cao Y, Li Y, Li J, et al. Comparison of 
three common DNA concentration measurement methods. Anal Biochem. 2014 Apr 15; (451): 18-24. DOI: 10.1016/j. ab.2014.01.016.

3. Nielsen K, Mogensen HS, Hedman J, Niederstätter H, Parson W, Morling N. Comparison of five DNA quantification methods. Forensic Science International: Genetics. 2008; 2 (3): 226-30.

4. He HJ, Stein EV, DeRose P, Cole KD. Limitations of methods for measuring the concentration of human genomic DNA and oligonucleotide samples. Biotechniques. 2018 Feb 1; 64 (2): 59-68. DOI: 10.2144/btn-2017-0102.

5. Nakayama $Y$, Yamaguchi $H$, Einaga N, Esumi M. Pitfalls of DNA Quantification Using DNA Binding Fluorescent Dyes and Suggested Solutions. PLoS ONE. 2016; 11 (3): e0150528. DOI 10.1371/journal.pone.0150528.

\section{Литература}

1. Bhat S, Curach N, Mostyn T, Bains GS, Griffiths KR, et al. Comparison of methods for accurate quantification of DNA mass concentration with traceability to the international system of units. Anal Chem. 2010 Sep 1; 82 (17): 7185-92. DOI: 10.1021/ ac100845m.

2. Li X, Wu Y, Zhang L, Cao Y, Li Y, Li J, et al. Comparison of three common DNA concentration measurement methods. Anal Biochem. 2014 Apr 15; (451): 18-24. DOI: 10.1016/j. ab.2014.01.016.

3. Nielsen K, Mogensen HS, Hedman J, Niederstätter H, Parson W, Morling N. Comparison of five DNA quantification methods. Forensic Science International: Genetics. 2008; 2 (3): 226-30.

4. He HJ, Stein EV, DeRose P, Cole KD. Limitations of methods for measuring the concentration of human genomic DNA and oligonucleotide samples. Biotechniques. 2018 Feb 1; 64 (2): 59-68. DOI: 10.2144/btn-2017-0102.
6. Belenikin MS, Galahova AA, Balanovskaya EV, Balanovsky OP. Ocenka vosproizvodimosti fluometricheskogo izmereniya koncentracii DNK. Genetika. 2018; (54): 113-6. DOI: 10.1134/ S0016675818130040. Russian.

7. Balanovskaya EV, Zhabagin MK, Agdzhoyan AT, Chukhryaeva MI, Markina NV, Balaganskaya OA, et al. Population biobanks: Organizational models and prospects of application in gene geography and personalized medicine. Russian Journal of Genetics. 2016; 52 (12): 1227-43.

8. Qubit dsDNA BR Assay Kits Manual (MAN0002325, Revision: A.0). Available from: https://tools.thermofisher.com/content/sfs/ manuals/Qubit_dsDNA_BR_Assay_UG.pdf.

5. Nakayama $Y$, Yamaguchi $H$, Einaga N, Esumi M. Pitfalls of DNA Quantification Using DNA Binding Fluorescent Dyes and Suggested Solutions. PLOS ONE. 2016; 11 (3): e0150528. DOI 10.1371/journal.pone.0150528.

6. Беленикин М. С., Галахова А. А., Балановская Е. В., Балановский О. П. Оценка воспроизводимости флуометрического измерения концентрации ДНК. Генетика. 2018; (54): 113-6. DOI: 10.1134/S0016675818130040.

7. Балановская Е. В., Жабагин М. К., Агджоян А. Т., Чухряева М. И., Маркина Н. В., Балаганская О. А. и др. Популяционные биобанки: принципы организации и перспективы применения в геногеограсии и персонализированной медицине. Генетика. 2016; (12): 1371-87.

8. Qubit dsDNA BR Assay Kits Manual (MAN0002325, Revision: A.0). Available from: https://tools.thermofisher.com/content/sfs/ manuals/Qubit_dsDNA_BR_Assay_UG.pdf. 